\title{
MEDIA GAMBAR YANG DIPROYEKSIKAN UNTUK MENINGKATKAN KETERAMPILAN MENULIS PUISI PADA SISWA KELAS 3 SD BANYURIPAN
}

\author{
SLIDE'S IMAGE PROJECTED MEDIA FOR IMPROVING POEM WRITING \\ SKILL ON THE THIRD GRADE OF BANYURIPAN ELEMENTARY SCHOOL
}

\author{
Isyani \\ SD Banyuripan UPT/PPD Kecamatan Kasihan Kabupaten Bantul \\ Kenalan Bangunjiwo Kasihan Bantul Yogyakarta, Indonesia \\ Email, isyani040@gmail.com
}

Diterima tanggal: 12 September 2016, dikembalikan untuk direvisi tanggal 25 September 2016, disetujui tanggal 09 Oktober 2016

\begin{abstract}
Abstrak: Penelitian ini bertujuan untuk mengetahui pengaruh media gambar yang diproyeksikan untuk meningkatkan kualitas pembelajaran dan hasil belajar menulis puisi pada siswa kelas III SD.Penelitian ini menggunakan metode Penelitian Tindakan Kelas (PTK) model Kemmis and Mc Taggart. Subyek penelitian adalah siswa kelas III SD Banyuripan yang berjumlah 16 siswa pada tahun pelajaran 2015-2016. Terdapat 4 indikator dalam penelitian ini, yaitu: (1) memperhatikan penjelasan guru tentang pembuatan puisi melalui gambar yang diproyeksikan, (2) menuliskan ide puisi dengan bantuan gambar yang diproyeksikan, (3) menentukan 4 kata kunci dengan bantuagambar yang diproyeksikan, dan (4) mengembangkan kata kunci menjadi bait puisi. Ada 4 indikator kompetensi menulis puisi, yaitu: (a) bunyi/rima, (b) diksi/pilihan kata, (c) bentuk visual, dan (d) makna. Hasil penelitian ini menunjukkan pembelajaran menggunakan media gambar yang diproyeksikan lebih tinggi daripada metode ceramah. Hal ini bisa dilihat pada: (1) prosentase ketuntasan menulis puisi yang lulus KKM mencapai 87,5\%, (2) Kualitas proses pembelajaran naik dari 70,83\% menjadi 90,62\%, (3) Nilai rerata hasil belajar siswa mengalami peningkatan dari 68,50 (dengan metode ceramah) menjadi 77,69 pada siklus I menjadi 81,06\% pada siklus II, (4) Temuan dalam penelitian ini adalah media gambar yang diproyeksikan dapat meningkatkan kompetensi menulis puisi siswa, namun diperlukan tambahan aktifitas pembelajaran yang berupa: (a) latihan menebak gambar, (b) menambah daftar kosa kata, dan (c) pemberian pedoman struktur kalimat lengkap dan tak lengkap.
\end{abstract}

Kata Kunci: Media gambar yang diproyeksikan, keterampilan menulis, puisi.

\begin{abstract}
The purpose of this research is to describe the application of slide image media in improving the skill of poem writing on the third grade of Banyuripan Elementary School, Kasihan, Bantul, Jogjakarta Province. This research was classroom action research method using Stephen Kemmis and Mc Taggart model. The subject of the research were sixteen students in the third grade of SD Banyuripan in the academic year 2015-2016. It was handle with two cycles. There are four indicators of learning process, thatare (1) giving the teacher's explanation about how to make a poem, (2) writing the idea of poem based on the slide's images (3) finding the four keywords based on the slide's images proyected, (4) developing the keywords become the poem. A good poem has four basic characteristics, included: (a) rhyme, (b) diction, (c) visual type, and (d) meaning. The analysis technique was quantitative descriptive approach. The concludes is the result of theresearch using slides' images is higher than ekspository method, they are: (1) the percentage of class competenceon poem writing over KKM (minimum competences) is $87,5 \%$. It is higher than the first cycle that was 50\%, (2) the quality of learning process increased from $70,83 \%$ to $90,62 \%$. (3) the averageclass score increased from 68,50 (using ekspository method) became $77,69 \%$ at first cycle to $81,06 \%$ at second cycle using slide's images proyected media, (4) the research findings is to increase the students' capability on writing poem is required three adding activities, those are: (a) excercises for guessing picture's content, and (b) providing vocabularies, (c) providing grammer guide, complete and uncomplete structure.
\end{abstract}

Keywords: Slide's images projected media, writing skill, poem. 


\section{PENDAHULUAN}

Bahasa Indonesia merupakan bahasa resmi Negara Republik Indonesia dalam komunikasi formal, baik secara lisan maupun tulisan. Sebagai bahasa resmi negara, kaidah berbahasa yang baik dan benar harus dipahami oleh masyarakat Indonesia. Tanpa pengetahuan kaidah yang benar, maka bahasa Indonesia akan kehilangan peran pentingnya dalam komunikasi sehari-hari dan tergusur oleh penggunaan bahasa lisan yang cenderung mudah berubah, mengikuti perkembangan budaya.

Bahasa Indonesia juga merupakan khasanah budaya bangsa. Banyak ragam bentuk sastra, baik prosa maupun puisi, yang memiliki nilai sastra tinggi yang menggunakan bahasa Indonesia. Ragam sastra Indonesia perlu dilestarikan agar bangsa Indonesia tidak kehilangan khasanah budaya dan jati dirinya. Salah satu upaya pembudayaan bahasa Indonesia yang baik dan benar adalah melalui pendidikan. Oleh sebab itu, pendidikan dasar hendaknya mengajarkan siswa untuk mengetahui dan mampu menggunakan bahasa Indonesia yang baik dan benar. Selain itu, siswa juga harus mampu menikmati karya sastra Indonesia dan menggunakan bahasa Indonesia untuk mengembangkan potensi seni sastra yang dimilikinya sesuai tingkat perkembangan masing-masing.

Ada empat keterampilan dasar yang diajarkan dalam pembelajaran bahasa Indonesia, yaitu: keterampilan menyimak, berbicara, membaca, dan menulis. Dari keempat aspek keterampilan berbahasa tersebut, secara umum, keterampilan menulis merupakan keterampilan yang paling sulit dikuasai siswa. Keterampilan ini melibatkan berbagai aktivitas, yaitu melalui pengalaman sehari-hari untuk mendapatkan ide melalui proses berpikir menuangkannya ke dalam bentuk tulisan.

Menulis merupakan suatu keterampilan berbahasa yang digunakan untuk berkomunikasi secara tidak langsung dan tidak tatap muka dengan orang lain. Menulis merupakan kegiatan yang produktif dan ekspresif (Tarigan, 2008:3). Salah satu keterampilan menulis yang digunakan untuk berkomunikasi secara tidak langsung adalah menulis puisi. Keterampilan menulis, khususnya puisi membutuhkan latihan berulang-ulang. Keterampilan menulis ini tidak akan datang secara otomatis, tetapi harus melalui latihan dan praktik yang banyak dan teratur (Tarigan, 2008). Menulis puisi yang indah lebih sulit daripada menulis prosa. Satu bait puisi yang baik, dapat mengungkap atau mewakili beberapa lembar tulisan dari prosa. Kesan yang kuat akan dapat dirasakan di dalam bait-bait sebuah puisi yang baik. Sebaliknya, sebuah puisi akan kehilangan daya tariknya jika bait-bait puisi hanya berisi rangkaian kata-kata biasa seperti halnya prosa.

Kemampuan menulis puisi merupakan keterampilan untuk mengungkapkan perasaan dan pikiran. Perasaan adalah sumber ide puisi yang memiliki potensi tak terbatas. Banyak puisi-puisi yang merupakan karya sastra tinggi yang berasal dari ungkapan perasaan dari pengalaman hidup penulisnya. Selain itu, hasil proses berpikir positifkreatif dapat diungkapkan dalam bentuk puisi. Berpikir positif kreatif dapat dipicu dengan adanya pengalaman nyata.

Mengingat sulitnya membuat puisi yang baik, maka pendekatan umum yang digunakan di Sekolah Dasar untuk membelajarkan keterampilan menulis puisi adalah menulis berdasarkan pengalaman sehari-hari siswanya. Meski demikian, ada beberapa kendala lain yang dihadapi guru dalam membelajarkan keterampilan menulis puisi yang baik, salah satunya adalah kendala waktu untuk memperoleh pengalaman yang sama bagi siswa dan guru. Pengalaman yang sama antara guru dan murid akan memudahkan guru untuk membimbing siswa mengungkapkan perasaan dan pikirannya dalam bentuk puisi.

Kemampuan menulis puisi siswa kelas III di SD Banyuripan, Kecamatan Kasihan, Kabupaten Bantul masih rendah. Hal ini didasarkan pada data selama 2 tahun terakhir di SD tersebut, yaitu pada tahun 2014 dan 2015. Pada tahun 2015, dari sebanyak 16 orang siswa kelas III, hanya terdapat 5 orang siswa (31\%) yang dapat menulis puisi sesuai kaidah yang diberikan. Nilai rata-rata kelas untuk kemampuan menulis puisi hanya mencapai 60 , jauh di bawah nilai KKM sebesar 75 . 
Ada beberapa faktor yang mungkin mempengaruhi hasil pembelajaran di atas, yaitu antara lain: siswa dan media pembelajaran. Sebagian besar siswa masih mengalami kesulitan dalam tiga hal pokok, yaitu: menemukan gagasan, menuangkan gagasan ke dalam kalimat yang benar, dan memilih kata yang tepat untuk mewakili gagasannya. Sebagian besar puisi karya siswa kelas III SD Banyuripan masih belum memenuhi syarat sebagai puisi yang baik dari segi struktur atau isinya.

Tampaknya penggunaan media pembelajaran diperlukan agar dapat mendukung pembelajaran keterampilan menulis puisi. Selama ini, pembelajaran menulis puisi hanya dengan mengandalkan pengalaman dan pengetahuan yang telah dimiliki anak. Sedangkan kemampuan anak untuk mengingat dan mengungkapkan apa yang diketahui atau dirasakan masih sangat terbatas. Oleh sebab itu, perlu media pembelajaran yang dapat merangsang kembali ingatan siswa terhadap pengalaman yang pernah dimiliki.

Salah satu media alternatif yang memungkinkan untuk digunakan dalam pembelajaran puisi adalah media gambar yang diproyeksikan. Gambar yang diproyeksikan mampu menangkap dan mengabadikan gambar suatu peristiwa atau kejadian. Gambar yang diproyeksikan yang tidak bergerak, lebih memungkinkan siswa untuk melihat lebih lama dan berkali-kali, dan berpikir berulang-ulang tehadap persitiwa yang terjadi di dalam gambar yang diproyeksikan. Namun demikian, bagaimana cara membelajarkan menulis puisi yang baik dan berhasil secara klasikal, bagi siswa SD dengan menggunakan media gambar yang diproyeksikan, tampaknya masih belum banyak dilakukan. Oleh sebab itu, tema ini cukup menarik untuk diteliti dengan penelitian tindakan kelas.

Penelitian yang relevan dengan topik yang akan dibahas adalah: (1) penelitian yang berjudul "Peningkatan Keterampilan Menulis Puisi melalui Model Picture and Picture dengan Media Gambar pada Siswa Kelas V SDN Gunungpati 01" (Maryanto, 2013) dan (2) (Hidayati, 2015) berjudul "Peningkatan Keterampilan Menulis Puisi Menggunakan Media Gambar pada Siswa Kelas III SDN Wonosari IV
Kabupaten Gunung Kidul". Kesimpulan kedua penelitian tersebut adalah bahwa media gambar dapat meningkatkan kemampuan menulis puisi siswa. Hal ini disebabkan media gambar dapat mengembangkan imajinasi dan membantu siswa dalam mengembangkan ide dan gagasannya dalam menulis puisi.

Berdasarkan uraian yang telah dikemukakan maka permasalahan penelitian dapat dinyatakan dalam 2 pertanyaan berikut: 1) bagaimana penggunaan media gambar yang diproyeksikan dalam pembelajaran menulis puisi pada pelajaran Bahasa Indonesia kelas III SD Banyuripan?. 2) apakah penggunaan media gambar yang diproyeksikan dapat meningkatkan keterampilan dan hasil belajar menulis puisi pada siswa kelas III SD Banyuripan?.

Tujuan dari penelitian ini adalah untuk: (1) mendeskripsikan penggunaan media gambar yang diproyeksikan dalam pembelajaran Bahasa Indonesia, khususnya di bidang peningkatan keterampilan menulis puisi siswa kelas III di SD Banyuripan Yogyakarta, dan (2) peningkatan keterampilan dan hasil belajar menulis puisi siswa kelas III SD Banyuripan.

\section{KAJIAN LITERATUR Pengertian Puisi}

Pada dasarnya banyak ragam rumusan pengertian puisi, karena puisi merupakan sebuah karya satra yang memiliki nilai seni tinggi, sehingga definisi dari puisi bisa berbeda-beda. Puisi adalah karya estetis yang memanfaatkan sarana bahasa secara khas (Sayuti, 2008:). Puisi sebagai sebuah karya seni sastra dapat dikaji dari bermacam-macam aspeknya. Puisi dapat dikaji dari aspek struktur dan unsur-unsurnya mengingat bahwa puisi itu adalah struktur yang terstruktur dari bermacam-macam unsur dan sarana-sarana kepuitisan (Pradopo, 2014).

Unsur-unsur yang dimansudkan antara lain dapat berupa bunyi (rima), pilihan kata (diksi), dan katakata kias (majas), tergantung pada penyair ingin memasukkan unsur yang mana di dalam puisinya. Salah satu usaha penyair untuk menciptakan sebuah puisi yang indah adalah memilih kata-kata yang 
memiliki perasaan bunyi (rima) yang tepat agar memiliki kekuatan pengucapan sehingga membentuk rima yang sesuai. Selain itu, penyair menentukan diksi dengan memilih kata-kata puitis yang memiliki makna yang lebih luas dan lebih banyak. Oleh karena itu, kata-kata dicarikan konotasi atau makna tambahannya dan dibuat bergaya dengan bahasa figurative untuk mendapatkan unsur majas yang tepat.

\section{Hakekat Menulis Puisi}

Menulis merupakan salah satu dari empat keterampilan berbahasa, yaitu menyimak, berbicara, membaca dan menulis. Setiap keterampilan mempunyai hubungan erat dengan keterampilan yang lainnya. Oleh karena itu, keterampilan menulis sudah tentu berhubungan dengan menyimak, berbicara dan membaca. Menulis kreatif merupakan tulisan yang bersifat apresiasif dan ekspresif. Apresiasif maksudnya bahwa melalui kegiatan menulis kreatif, seseorang dapat mengenali, menyenangi, menikmati, dan mungkin juga menciptakan kembali secara kritis berbagai hal yang dijumpai dalam teks-teks kreatif karya orang lain dengan caranya sendiri dan memanfaatkan berbagai hal tersebut kedalam kehidupan nyata. Ekpresif dalam arti bahwa kita dimungkinkan mengekpresikan atau mengungkapkan berbagai pengalaman atau berbagai hal yang menggejala dalam diri kita untuk dikomunikasikan kepada orang lain melalui tulisan kreatif sebagai sesuatu yang bermakna (Triyanto, 2009).

Salah satu teks yang bersifat kreatif adalah teks puisi. Menulis kreatif pada hakikatnya adalah menafsirkan kehidupan ke dalam bentuk tulisan yang kreatif dan inspiratif seperti dalam bentuk puisi. Seorang penulis biasanya ingin mengkomunikasikan sesuatu kepada pembaca melalui karyanya, misalnya dapat saja tentang pengalaman dalam kehidupannya yang menjadi sumber inspirasinya.

\section{Unsur-Unsur dalam Puisi}

Sebuah tulisan dapat disebut sebagai puisi apabila harus memenuhi unsur-unsur sebuah puisi yang antara lain adalah sebagai berikut:
Pertama, bunyi/rima merupakan penanda yang dapat diamati melalui pendengaran dan atau penglihatan. Salah satu peran utama bunyi dalam puisi adalah agar puisi itu merdu jika didengarkan, sebab pada hakikatnya puisi adalah untuk didengar. Rima atau pola persajakan yakni bunyi yang berselang/berulang, baik di dalam maupun di akhir lirik yang di dalamnya mengandung berbagai aspek (Sayuti, 2008).

Kedua, diksi/pilihan kata. Peranan diksi dalam puisi sangat penting karena kata-kata adalah segalagalanya di dalam puisi. Begitu pentingnya diksi di dalam puisi sehingga ada yang menyatakan bahwa diksi merupakan esensi penulisan puisi. Bahkan ada yang menyebutnya sebagai dasar bangunan setiap puisi sehingga dikatakan pula bahwa diksi merupakan faktor penentu seberapa jauh seorang penyair mempunyai daya cipta yang asli (Sayuti, 2008)

Ketiga, bentuk visual. Bentuk visual merupakan salah satu unsur puisi yang paling mudah dikenal. Bentuk visual meliputi penggunaan tipograsi dan susunan baris (bait). Peranan bait adalah untuk menciptakan topografi puisi dan menciptakan penekanan gagasan serta loncatan gagasan. Tipografi dalam puisi berfungsi sebagai penampilan yang artistik dan memberikan nuansa makna serta suasana tertentu. Contoh bentuk visual di antaranya bentuk visual seperti prosa, bentuk visual konvensional, bentuk visual zig zag.

Keempat, makna. Makna merupakan wilayah isi sebuah puisi. Setiap puisi pasti mengandung makna, baik makna yang disampaikan secara langsung maupun secara tak langsung, implisit atau simbolis. Makna tersebut biasanya berkaitan dengan apa yang dialami dalam kehidupan manusia. Makna puisi, pada umumnya baru dapat dipahami setelah seorang pembaca membaca, memahami arti tiap kata kiasan yang dipakai dalam puisi, dan juga memperhatikan unsur-unsur puisi lainnya yang mendukung makna (Wiyatmi, 2006).

\section{Media Gambar yang Diproyeksikan Sebagai Media untuk Menulis Puisi}

Media pembelajaran berperan penting dalam menunjang keberhasilan proses belajar-mengajar. 
Salah satu fungsi media pembelajaran adalah sebagai alat bantu yang digunakan guru ketika mengajar untuk membantu memperjelas materi yang disampaikan dan mengurangi proses pembelajaran secara verbalisme. Media dapat diklasifikasikan menjadi tiga golongan, yaitu sebagai berikut.

Pertama, Media visual merupakan media yang hanya dapat dipandang. Media ini dapat dibagi menjadi: (a) media visual yang tidak diproyeksikan atau media yang tidak dapat dipantulkan layar. Beberapa media yang termasuk jenis ini, antara lain adalah: gambar mati, ilustrasi, karikatur, poster, bagan, diagram, grafik, peta, diagram, dll. (b) media visual yang diproyeksikan atau media yang dapat diproyeksikan (dipantulkan) pada layar karena bahan yang dipakai tembus pandang (transparan). Media ini dapat diproyeksikan pada bebepapa jenis proyektor, antara lain pada Over Head Proyektor (OHP), slide proyektor, film strip projector; sedangkan yang diproyeksikan pada layar antara lain dapat berupa tulisan, gambar, peta, diagram.

Kedua, Media audio. Media audio merupakan jenis media yang hanya dapat didengar. Media ini perlu dipelajari karena dalam menerima pelajaran dari guru, siswa selalu mendengarkan. Bentuk-bentuk program audio, antar lain adalah wawancara, berita radio, warta berita, diskusi, dan seminar.

Ketiga, Media audio visual. Selain dapat didengar, media ini juga dapat dipandang (dilihat, diamati). Contohnya, film dan televisi. Televisi merupakan jenis media yang menampilkan gambar bergerak. Sumbersumber gambar dan suara dari jarak jauh dapat dihadirkan di sekolah, di rumah, dan di berbagai tempat lainnya melalui layar kaca (Sardjiyo, 2014).

Media gambar yang diproyeksikan termasuk ke dalam media visual yang dapat diproyeksikan atau dipantulkan melalui OHP atau slide projector. Model pembelajaran ini menggunakan sarana komputer atau laptop dan LCD projector, sehingga dapat disebut sebagai pembelajaran berbasis komputer. Media pembelajaran berbasis komputer atau yang biasa disebut sebagai pembelajaran berbantuan komputer (Computer Assisted Instructional/CAl) merupakan salah satu media pembelajaran yang sangat menarik dan mampu meningkatkan motivasi belajar peserta didik (Warsita, 2008). Untuk membuat bahan belajar yang akan ditayangkan melalui LCD projector, biasanya digunakan Microsoft office power point. Program ini bisa menampilkan teks, gambar, foto, grafik, audio, video, dan animasi.

Sajian materi pembelajaran yang menggunakan teknik presentasi power point (ppt) memiliki beberapa kesamaan dengan media transparasi yang dalam penggunaanya diperlukan alat bantu berupa proyektor yang berfungsi memproyesikan gambar ke layar, atau dalam ukuran besar. Adapun kelebihan dari media gambar yang diproyeksikan ini antara lain adalah: (1) urutan gambar dapat diubah-ubah sesuai dengan kebutuhan, (2) lembar sajian (slides) dapat ditayangkan lebih lama untuk menarik perhatian dan membangun persepsi yang sama terhadap konsep atau pesan yang disampaikan, (3) lembar sajian (slides) dapat ditayangkan pada ruangan yang masih terang (tidak perlu benar-benar gelap). Jika tidak terdapat layar khusus, dindingpun dapat dijadikan pengganti layar, (4) lembar sajian (slides) dapat digunakan sendiri atau digabung dengan suara/ rekaman, (5) lembar sajian (slides) dapat menyajikan peristiwa masa lalu atau peristiwa di tempat lain. Di samping itu, lembar sajian (slides) juga bisa menampilkan obyek yang besar, berbahaya, atau terlalu kecil untuk dapat dilihat dengan mata, dapat ditayangkan dengan jelas (Arsyad, 2015:48-49).

Pembelajaran menulis puisi terdiri dari beberapa tahap, yaitu antara lain: (1) menentukan ide. Ide disebut juga tema atau gagasan yang merupakan tahap awal dalam menulis puisi. Keberhasilan menulis puisi sangat ditentukan oleh penentuan ide atau tema yang tepat; (2) mengembangkan ide menjadi kata kunci. Setelah menuliskan tema atau ide, langkah menulis puisi selanjutnya adalah menentukan beberapa kata kunci sesuai ide atau tema; (3) merangkai kata kunci menjadi bait puisi. Kata kunci yang telah ditulis kemudian dikembangkan menjadi bait puisi dengan cara menyusun kata-kata, larik-larik puisi menjadi satu puisi yang indah dan penuh makna; dan (4) menentukan judul yang sesuai denga isi yang terkandung di dalam puisi.

Berdasarkan tahapan penulisan puisi di atas, langkah-langkah pembelajaran menggunakan media 
gambar yang diproyeksikan dalam penelitian ini menggunakan 3 tahap, yaitu:

Pertama, kegiatan pendahuluan. Dalam kegiatan ini, guru memberikan apersepsi, menyampaikan kompetensi dasar yang harus dicapai siswa, tujuan pembelajaran serta memberi motivasi kepada siswa untuk menciptakan suasana pembelajaran yang menyenangkan.

Kedua, kegiatan inti. Pada tahap ini, guru menyampaikan materi tentang definisi puisi, unsurunsur puisi, contoh puisi, tahap-tahap membuat puisi, serta demontrasi pembuatan puisi menggunakan media gambar yang diproyeksikan. Tahap ini diawali dengan penayangan gambar yang diproyeksikan secara bertahap selama proses pembuatan puisi, dimulai dari slide pertama untuk menuliskan ide utama puisi, slide kedua, untuk menuliskan kata kunci pertama, slide ketiga, keempat, kelima untuk menuliskan kata kunci kedua, ketiga dan keempat, slide kelima untuk membantu siswa merangkai kata kunci menjadi bait puisi. Kemudian pada tahap evaluasi, guru kembali menayangkan gambar yang diproyeksikan dan siswa mulai menulis puisi berdasarkan tahapan yang sudah dijelaskan, mulai dari menuliskan ide sesuai tampilan di gambar yang diproyeksikan, merangkai ide menjadi kata kunci, dan merangkai kata kunci menjadi bait puisi.

Ketiga, kegiatan penutup. Pada tahap ini, guru merangkum materi yang telah disampaikan, memberi kesempatan kepada siswa untuk bertanya dan melakukan refleksi terhadap proses pembelajaran yang telah dilaksanakan. Penilaian dilakukan dengan melihat hasil puisi siswa berdasarkan kriteria yang telah ditentukan.

\section{Pengertian Metode Ceramah dan Pendekatan Ekspositori}

Ceramah adalah pidato yang disampaikan oleh seorang pembicara di depan kelompok pengunjung (dalam hal ini siswa). Metode ini sangat baik jika digunakan untuk jumlah siswa yang banyak. Selain itu, sangat baik juga untuk menjelaskan materi yang banyak, namun waktu terbatas (Sardjiyo,dkk,2014) Sampai sekarang, metode ini masih banyak digunakan guru karena metode ini bisa dikatakan tidak terlalu banyak memerlukan persiapan. Hanya dalam penerapan metode ini, guru dituntut harus benar-benar menguasai materi yang akan diajarkan. Pendekatan pembelajaran yang sesuai dengan metode ini adalah pendekatan ekspositori.

Pendekatan ekspositori adalah strategi yang menekankan proses penyampaian materi secara verbal dari seorang guru kepada sekelompok siswa dengan maksud agar siswa dapat menguasai materi pelajaran secara optimal (Sanjaya,2008). Motode ekspositori dengan istilah pengajaran langsung (direct instruction) karena dalam metode ini, materi pelajaran disampaikan langsung oleh guru, siswa tidak dituntut untuk menemukan materi itu sendiri (Sanjaya, 2008).

Model pembelajaran ini memposisikan guru sebagi sumber belajar yang utama karena pembelajaran berpusat pada guru (teacher centered). Siswa hanya menerima materi pelajaran yang disampaikan guru secara verbal. Pada awal pembelajaran model ini, biasanya seorang guru memulai dengan memberikan ceramah tentang materi yang dipelajari, memberikan contoh soal, melakukan tanya jawab, dan diakhiri dengan pemberian tugas.

Karakteristik strategi pembelajaran ekspositori adalah: 1) strategi ekspositori dilakukan dengan cara menyampaikan materi pelajaran secara verbal, yaitu bertutur kata secara lisan merupakan alat utama dalam menyampaikan materi utama (ceramah); 2) biasanya materi yang disampaikan adalah materi pelajaran yang sudah jadi, seperti data atau fakta, konsep-konsep tertentu; 3) tujuan utama pembelajaran adalah penguasaan materi pelajaran itu sendiri. Artinya setelah proses pembelajaran berakhir, siswa diharapkan dapat memahami dengan benar dan dengan cara yang tepat, dapat mengungkapkan kembali materi yang telah disampaikan (Sanjaya, 2008).

Dalam penerapan strategi pembelajaran ekspositori terdapat beberapa prinsip, yaitu: (1) berorientasi pada tujuan, penyampaian materi pelajaran merupakan ciri utama dalam strategi pembelajaran ekspositori melalui metode ceramah, namun tidak berarti proses penyampaian materi tanpa tujuan pembelajaran, maka dari itu sebelum strategi 
ini diterapkan terlebih dahulu guru harus merumuskan tujuan pembelajaran secara jelas dan terukur; (2) prinsip komunikasi, proses pembelajaran dapat dikatakan sebagai proses komunikasi, yang menunjuk pada proses penyampaian pesan dari sumber pesan kepada seseorang atau kelompok orang (penerima pesan). Guru berfungsi sebagai sumber pesan dan siswa sebagi penerima pesan dalam proses komunikasi; (3) siswa dapat menerima informasi sebagai stimulus yang kita berikan, terlebih dahulu kita harus memposisikan mereka dalam keadaan siap baik secara fisik maupun psikis untuk menerima pelajaran; dan (4) prinsip keberlanjutan, proses pembelajaran ekpositori harus dapat mendorong siswa mau mempelajari materi pelajaran lebih lanjut (Sanjaya, 2008).

Selanjutnya langkah-langkah desain pembelajaran pada tahap pra siklus menggunakan metode ceramah/ekspositori yang pada penelitian ini mencakup 3 tahap, yaitu: 1) kegiatan pendahuluan, apersepsi, memberi motivasi, menjelaskan tujuan pembelajaran yang akan dicapai, dan melakukan pre test untuk menguji kemampuan awal siswa; 2) kegiatan inti, yang berisi penyajian materi yang berupa penjelasan isi materi, pemberian contohcontoh puisi sederhana, memberi pertanyaan sebagai upaya mengaktifkan kegiatan siswa, dan latihan menulis puisi; 3) kegiatan penutup, sebagai kegiatan terakhir dalam proses pembelajaran. Pada tahap ini, guru menyimpulkan materi tentang puisi, memberi kesempatan pada siswa untuk bertanya tentang halhal yang belum jelas, dan siswa mengumpulkan hasil puisi yang telah ditulis.

\section{METODE PENELITIAN}

Penelitian ini merupakan Penelitian Tindakan Kelas (PTK), yaitu sebuah kegiatan penelitian yang dilakukan di dalam kelas, yang bertempat di SD Banyuripan Kecamatan Kasihan Kabupaten Bantul sebayak 2 siklus menggunakan media gambar yang diproyeksikan. Subyek penelitian ini adalah siswa kelas III SD Banyuripan yang berjumlah 16 siswa pada semester I tahun pelajaran 2015/2016. Penelitian ini dilaksanakan dengan mengikuti prosedur penelitian yang dikembangkan oleh Stephen
Kemmis dan Taggart, dalam Arikunto (2010:16). Tahapan dalam penelitian tindakan kelas ini disebut siklus, dan setiap siklusnya mencakup kegiatan perencanaan (planning), tindakan (action), pengamatan (observation), dan refleksi (reflection).

\section{Perencanaan (planning)}

Pada tahap perencanaan, peneliti menyusun rancangan atau rencana tindakan yang akan dilaksanakan pada proses belajar mengajar. Perhatian utama yang diamati yaitu pembelajaran menulis puisi dengan menggunakan media gambar yang diproyeksikan. Kegiatan yang dilakukan antara lain: (a) menyusun skenario pembelajaran dengan metode gambar yang diproyeksikan, (b) menyusun dan menyiapkan media pembelajaran, berupa laptop, bahan belajar gambar yang diproyeksikan dalam bentuk powerpoint, proyektor $L C D$, (c) merancang dan mempersiapkan instrument/lembar observasi sebagai pedoman, dan (d) menyusun dan mempersiapkan lembar evaluasi untuk menulis hasil puisi siswa guna mengukur kemampuan siswa dalam menulis puisi dengan media gambar yang diproyeksikan.

Pada penelitian ini, yang dijadikan tolok ukur pelaksanaan penelitian adalah kemampuan menulis puisi berdasarkan gambar yang diproyeksikan. Indikator kriteria kompetensi penulisan puisi yang diperhatikan adalah: (a) siswa dapat menulis puisi dengan unsur bunyi yang benar, (b) siswa dapat menentukan pilihan kata/diksi yang tepat, (c) siswa dapat menulis puisi dengan bentuk visual yang tepat, dan (d) siswa dapat menulis puisi sesuai dengan makna berdasarkan gambar yang diproyeksikan.

\section{Pelaksanaan Tindakan (acting)}

Pada tahap ini, peneliti melakukan tindakan sebagai upaya perubahan untuk melaksanakan perbaikan kegiatan belajar-mengajar pada keterampilan menulis puisi dengan menggunakan media gambar yang diproyeksikan. 


\section{Observasi (observation)}

Pengamatan dilakukan secara sistematis oleh peneliti untuk mengamati hasil atau dampak tindakan terhadap proses belajar-mengajar, situasi tempat tindakan dan hambatan-hambatan yang ditemukan saat pelaksanaan tindakan dengan dibantu oleh supervisor II sebagai pengamat. Data non tes diperoleh dengan menggunakan pedoman pengamatan, dan dokumentasi foto. Semua dicatat dalam kegiatan observasi yang terencana dengan menggunakan lembar observasi yang telah disiapkan. Pengamatan proses pembelajaran berguna sebagai pendokumentasian dan informasi data sebagai pedoman pada kegiatan refleksi yang akan berpengaruh terhadap tindakan pada siklus berikutnya.

\section{Refleksi (reflection)}

Refleksi dilakukan dengan cara merenungkan kembali proses pembelajaran berdasarkan hasil observasi proses pembelajarn dan hasil belajar, baik mengenai kekurangannya maupun keberhasilan pembelajaran bagi siswa. Peneliti merefleksi apakah media gambar yang diproyeksikan dapat meningkatkan hasil belajar siswa. Dengan demikian, akan dapat diketahui kelemahan tindakan pembelajaran yang perlu diperbaiki pada siklus berikutnya.

Teknik pengumpulan data menggunakan observasi langsung dan portofolio berupa karya puisi siswa. Instrumen dalam penelitian ini adalah lembar observasi proses pembelajaran yang terdiri dari empat indikator, yaitu: (1) memperhatikan penjelasan guru tentang pembuatan puisi melalui media gambar yang diproyeksikan, (2) menulis ide puisi dengan bantuan gambar yang diproyeksikan, (3) menentukan empat kata kunci dengan bantuan gambar yang diproyeksikan, dan (4) mengembangkan kata kunci menjadi bait puisi. Kompetensi menulis puisi, terdiri dari empat indikator, yaitu kemampuan untuk: (1) menyusun rima, (2) memilih kata (diksi), (3) menyusun bentuk visual puisi, dan (4) kebermaknaan puisi.

Teknik analisa data menggunakan tehnik sebagai berikut, Pertama, analisis data kuantitatif (hasil tes). Penilaian prestasi belajar siswa diambil melalui tes evaluasi pada akhir pembelajaran setiap siklus. Pada pelaksanaan tes ini, siswa diminta menulis puisi berdasarkan gambar yang diproyeksikan atau ditayangkan secara bertahap. Penilaian hasil evaluasi dilakukan berdasarkan kriteria kompetensi yang telah ditentukan. Nilai hasil belajar siswa dapat diketahui dengan rumus:

Nilai akhir $=\frac{\text { jumlah skor yang diperoleh }}{\text { skor maksimal }} \times 100$

Kedua, analisis data kualitatif (hasil observasi). Data hasil observasi dianalisis dengan menggunakan metode analisis deskriptif. Tujuan penggunaan metode analisis deskriptif adalah untuk memberikan gambaran pelaksanaan proses pembelajaran dengan menggunakan media gambar yang diproyeksikan dan menggunakan 4 indikator keaktifan siswa yang telah ditentukan sebelumnya.

Nilai akhir keaktifan siswa $=$

$$
\frac{\text { jumlah skor indikator yang diperoleh }}{\text { jumlah skorindikator maksimal }} \times 100
$$

Ketiga, analisis ketuntasan belajar siswa. Analisis tes ketuntasan hasil belajar siswa dimaksudkan untuk mengetahui tingkat ketuntasan belajar siswa yang diperoleh tiap siklus. Untuk mengukur ketuntasan belajar keseluruhan menggunakan rumus:

Ketuntasan belajar siswa $=$

$$
\frac{\text { jumlah siswa tuntas belajar }}{\text { jumlah siswa }} \times 100
$$

Target keberhasilan dalam penelitian ini adalah meningkatnya kemampuan menulis puisi siswa setelah menggunakan media gambar yang diproyeksikan, yang ditandai dengan minimal 80\% dari jumlah siswa mampu menulis puisi dengan skor KKM 75, dan meningkatnya rerata hasil belajar menulis puisi.

\section{HASIL DAN PEMBAHASAN}

Penelitian tindakan kelas ini dilaksanakan dalam 2 siklus yang terdiri dari 4 kegiatan, yaitu perencanaan, tindakan, observasi, dan refleksi. 


\section{Pra Siklus (Menggunakan Metode Ceramah)}

Pada tahap pra siklus, proses pembelajaran pada penelitian ini masih menggunakan metode ceramah dengan pendekatan ekspositori. Hasil ketuntasan belajar yang dicapai baru mencapai $25 \%$ atau baru 4 siswa yang sudah mencapai ketuntasan belajar, sedangkan 12 siswa (75\%) belum mencapai nilai ketuntasan minimal menulis puisi. Rerata hasil belajar hanya mencapai skor 68,50.

\section{Pembelajaran Melalui Media Gambar yang diproyeksikan \\ Deskripsi Siklus Pertama}

Pada tahap perencanaan siklus pertama, ada beberapa hal yang perlu disiapkan, yaitu: (1) RPP, (2) lembar observasi, (3) lembar kegiatan siswa, (4) alat peraga media, yaitu: laptop dan LCD proyektor, (5) media pembelajaran gambar yang diproyeksikan menggunakan Microsoft office Powerpoint, dan (6) Contoh-contoh puisi sederhana untuk siswa SD.

Pada saat pelaksanaan siklus pertama, dilakukan pendokumentasian proses pembelajaran menulis puisi menggunakan instrumen pengamatan yang telah disiapkan. Adapun tindakan yang dilakukan dalam proses pembelajaran, secara garis besar adalah: (1) guru menjelaskan pengertian puisi, unsurunsur puisi dan tahapan menulis puisi, (2) guru menampilkan gambar melalui proyektor LCD dan mendemontrasikan tahap-tahap menulis puisi berdasarkan gambar yang diproyeksikan.

Sedangkan prosedur dan tahap-tahap menulis penggunaan media gambar yang diproyeksikan pada siklus pertama ini adalah: (1) guru menampilkan gambar yang diproyeksikan di depan kelas, (2) siswa mengamati gambar dan diminta menemukan dan menuliskan satu kata sebagai ide puisi dari tampilan gambar yang diproyeksikan, (3) siswa diminta menuliskan 1 kata kunci berdasarkan tampilan gambar yang diproyeksikan, (4) guru menampilkan 4 jenis gambar berbeda secara bergantian dan siswa diminta menuliskan 1 kata kunci pada setiap gambar, (5) siswa diminta mengembangkan tiap kata kunci menjadi satu baris puisi, (6) siswa diminta menuliskan judul puisi berdasarkan kata dari ide puisi.

Pada tahap observasi siklus pertama, kegiatan siswa dicatat selama proses pembelajaran. Hasil observasi kegiatan siswa dalam proses pembelajaran menggunakan media gambar yang diproyeksikan adalah sebagai berikut:

Tabel 1: Skor Indikator Proses Pembelajaran

\begin{tabular}{llccl}
\hline No & Uraian & $\begin{array}{c}\text { Skor } \\
\text { mak }\end{array}$ & $\begin{array}{c}\text { Skor } \\
\text { Indikator }\end{array}$ & Rerata\% \\
\hline 1 & Indikator 1 & 64 & 49 & 76,56 \\
2 & Indikator 2 & 64 & 43 & 67,19 \\
3 & Indikator 3 & 64 & 50 & 78,12 \\
4 & Indikator 4 & 64 & 50 & 78,12 \\
5 & Rerata kelas & & 70,83 \\
\multicolumn{5}{c}{ Sumber: data primer, 2015 } \\
\end{tabular}

Dari keempat indikator di atas, indikator 2 (menulis ide puisi dari gambar yang diproyeksikan) ternyata masih sangat rendah yaitu baru mencapai 67,19\%; sedangkan ketiga indikator lainnya juga masih belum sesuai target yang dikehendaki. Kompetensi hasil belajar siswa dalam menulis puisi adalah sebagai berikut:

Tabel 2: Rerata Hasil Belajar Menulis Puisi

\begin{tabular}{lll}
\hline No & Uraian & Rerata \\
\hline 1 & Indikator A & 74,50 \\
2 & Indikator B & 76,56 \\
3 & Indikator C & 75,75 \\
4 & Indikator D & 72,25 \\
\hline 5 & Rerata kelas & \\
& Hasil Belajar & 74,89 \\
\hline
\end{tabular}

Sumber: data primer, 2015

Dari keempat indikator di atas, indikator B (menulis ide puisi dari gambar yang diproyeksikan) ternyata

masih sangat rendah; sedangkan ketiga indikator lainnya juga masih belum sesuai target yang dikehendaki.

Sementara rerata kompetensi menulis puisi yang terdiri dari 4 indikator, yaitu indikator A (bunyi/rima) mencapai 74,50, indikator B (diksi/pilihan kata) mencapai 76,56 , indikator $C$ (bentuk visual) mencapai 75,75 , dan indikator D (makna) mencapai 77,25 . Nilai rata-rata kelas hasil menulis puisi mencapai 74,89. Dengan demikian, dapat dilihat bahwa skor rerata setiap indikator yang masih dibawah 75 adalah indikator A, yaitu: kemampuan menyusun rima. Sedangkan tiga kemampuan lainnya juga masih pada 
tahap kemampuan minimal, yaitu: memilih kata, menyusun bentuk visual, dan makna puisi. Selanjutnya deskripsi skor yang diperoleh siswa dari evaluasi berbentuk portofolio puisi karya siswa adalah sebagai berikut:

Tabel 3: Data Nilai dan Ketuntasan Siswa

\begin{tabular}{llc}
\hline \multicolumn{2}{l}{ No Aspek } & Skor / Jumlah \\
\hline 1. & Nilai Tertinggi & 90 \\
\hline 2. & Nilai Terendah & 40 \\
\hline 3. & Rerata kelas & 74,89 \\
\hline 4. & Ketuntasan belajar (nilai>75) & 8 siswa (50\%) \\
\hline 5. & Ketidak tuntas belajar (nilai< 75) & 8 siswa (50\%) \\
\hline 6. & Rerata Ketuntasan Siswa & $50 \%$ \\
\hline
\end{tabular}

Sumber: data primer, 2015

Dari Tabel 3, diketahui bahwa jumlah siswa yang telah mencapai ketuntasan belajar baru mencapai 8 siswa dari 16 siswa (50\%). Kondisi ini masih jauh dari target sebesar 80\% siswa mencapai nilai KKM.

Pada tahap refleksi, dihasilkan beberapa kelebihan dan kekurangan proses pembelajaran pada siklus pertama ini. Kelebihan proses pembelajaran pada siklus ini adalah ada tiga indikator yang telah mencapai skor minimum, yaitu: (1) mendengar penjelasan guru tentang teori puisi $(76,56 \%),(2)$ menentukan 4 kata kunci dengan bantuan gambar yang diproyeksikan (78,12\%), dan (3) mengembangkan kata kunci menjadi bait puisi (78,12\%). Namun demikian, indikator pembelajaran ini masih perlu untuk ditingkatkan lagi. Sedangkan kekurangan proses pembelajaran, terlihat dari indikator 2, yaitu: menuliskan ide puisi berdasarkan gambar yang diproyeksikan $(67,19 \%)$. Dari rerata skor kelas terhadap hasil belajar kompetensi menulis puisi siswa menunjukkan bahwa kemampuan siswa dalam menulis puisi juga masih belum memuaskan, yaitu baru mencapai nilai rata-rata kelas sebesar 74,89. Secara umum, kelemahan proses pembelajaran pada siklus pertama ini, adalah: rendahnya kemampuan menuliskan ide dari gambar yang diproyeksikan (indikator2), yang mungkin disebabkan ketidakberanian dan keragu-raguan siswa untuk menuliskan ide sesuai gambar yang diproyeksikan yang dilihatnya. Di samping itu, ada indikator proses pembelajaran yang masih perlu ditingkatkan, yaitu: (1) rendahnya perhatian siswa terhadap penjelasan guru, (2) rendahnya kemampuan memilih kata kunci dari gambar yang diproyeksikan yang ditayangkan, dan (3) rendahnya kemampuan mengembangkan kata kunci menjadi bait puisi.

Berdasarkan kelemahan proses belajar pada siklus I, maka diajukan rekomendasi untuk perbaikan pada siklus berikutnya, yaitu: (1) perlu latihan menebak gambar sebagai latihan menuliskan ide puisi. Latihan menebak gambar merupakan permainan menarik untuk membiasakan dan meningkatkan kepercayaan diri siswa dalam mengungkapkan pendapatnya, (2) guru perlu membuat presentasi yang menarik dan dialog interaktif agar siswa lebih tertarik mendengar penjelasannya, (3) perlu dibuat daftar kosa kata-kata kunci sebagai bantuan bagi siswa untuk memudahkan memilih dan mengembangkan kata kunci, (4) perlu dibuat panduan kalimat lengkap dan tak lengkap untuk membuat bait puisi.

\section{Deskripsi Siklus Kedua}

Pada tahap perencanaan, disiapkan instrumen yang diperlukan yaitu, (1) RPP, (2) lembar pengamatan/observasi, (3) alat peraga media, yaitu: laptop, proyektor LCD, (4) materi ajar dalam bentuk Powerpoint dalam yang lebih variatif untuk permainan tebak gambar, (5) materi pembelajaran dalam bentuk Powerpoint untuk menulis puisi, (6) daftar kosa kata, dan (7) lembar portofolio hasil puisi siswa.

Pada tahap pelaksanaan, dicatat kegiatan siswa selama proses perbaikan pembelajaran dengan menggunakan instrumen pengamatan yang telah disiapkan. Pada tahap ini ada beberapa perubahan strategi yang dilakukan guru, sesuai pada hasil rekomendasi dari refleksi siklus pertama. Langkahlangkah pembelajaran pada siklus kedua ini diawali dengan: (1) guru melakukan permainan tebak gambar, dengan cara guru menampilkan gambar bermacam-macam yang diproyeksikan secara bergantian, kemudian siswa menulis ide berdasarkan gambar yang dilihatnya, (2) guru menampilkan sebuah gambar dan bersama-sama siswa menuliskan daftar kosa kata yang sesuai dengan 
gambar yang diproyeksikan, (3) guru memberi penjelasan pedoman struktur kalimat lengkap dan tak lengkap, untuk mengembangkan cara menulis puisi supaya mempunyai bentuk tulisan yang seimbang antarbaris puisi, dan (4) guru menampilkan gambar dan mendemontrasikan cara tahap-tahap menulis puisi yang benar sesuai gambar yang diproyeksikan.

Prosedur penggunaan media gambar yang diproyeksikan pada siklus kedua, setelah pembelajaran diawali dengan berbagai kegiatan pendukung untuk mempermudah siswa menulis puisi, adalah: (1) guru menampilkan sebuah gambar yang diproyeksikan dan siswa diminta menuliskan ide pokok dari puisi, (2) guru menampilkan 4 jenis gambar yang sesuai dengan tema dan siswa diminta menuliskan 1 kata kunci pada setiap gambar. Pada siklus kedua ini, gambar-gambar yang ditampilkan diberi tambahan animasi gerak dan suara sehingga memudahkan siswa untuk menuliskan kata kunci pada setiap gambar, (3) siswa diminta mengembangkan setiap kata kunci menjadi satu baris puisi. Pada siklus ini, sudah disediakan kosa kata yang sesuai dengan tema, sehingga memudahkan siswa dalam memilih kata-kata untuk mengembangkannya menjadi bait puisi, (4) siswa diminta menuliskan judul puisi berdasarkan isi dalam puisi, dan (5) siswa diminta meneliti kembali puisi yang telah dibuat apakah sudah sesuai prosedur penulisan puisi yang telah disampaikan sebelumnya.

Pada tahap observasi, hasil pengamatan proses pembelajaran terhadap kegiatan belajar siswa, dapat dilihat pada Tabel 4, berikut ini.

Tabel 4: Skor Indikator Proses Pembelajaran

\begin{tabular}{llccl}
\hline No. & Uraian & $\begin{array}{r}\text { Skor } \\
\text { mak }\end{array}$ & $\begin{array}{c}\text { Skor } \\
\text { Indikator }\end{array}$ & Rerata\% \\
\hline 1. & Indikator 1 & 64 & 54 & 84,37 \\
2. & Indikator 2 & 64 & 55 & 85,93 \\
3. & Indikator 3 & 64 & 56 & 86,5 \\
4. & Indikator 4 & 64 & 57 & 89,06 \\
\hline 5. & Rerata kelas & & & 90,62 \\
\hline
\end{tabular}

Sumber: data primer, 2015

Berdasarkan data di atas, dapat diketahui bahwa pada siklus kedua, dari 16 siswa kelas III, terdapat peningkatan kualitas kegiatan siswa. Hal ini dapat dilihat melalui capaian indikator-indikator pembelajaran, yaitu: indikator 1 mencapai keberhasilan 84,37\%, indikator 2 mencapai keberhasilan 85,93\%, indikator 3 mencapai keberhasilan $86,5 \%$, dan indikator 4 mencapai keberhasilan 89,06\%. Rata-rata keberhasilan nilai kelas proses pembelajaran mencapai 90,62\%.

Tabel 5: Rerata Hasil Belajar Menulis Puisi

\begin{tabular}{lll}
\hline No. & Uraian & Rerata \\
\hline 1. & Indikator A & 80 \\
2. & Indikator B & 80 \\
3. & Indikator C & 82,13 \\
4. & Indikator D & 80,75 \\
\hline 5. & Rerata kelas hasil belajar & 81,14 \\
\hline \multicolumn{3}{c}{ Sumber: data primer, 2015 }
\end{tabular}

Pada siklus II, nilai rerata hasil belajar kompetensi menulis puisi siswa mengalami kenaikan dari siklus I, yaitu indikator A dari 74,5 menjadi 80, indikator B dari 76,56 menjadi 80 , indikator $C$ dari 75,75 menjadi 80,75 dan indikator $D$ dari 77,25 menjadi 80,75 . Hasil rata-ratanya juga meningkat dari 74,89 menjadi 81,14. Data skor rerata dan ketuntasan belajar siswa dapat dilihat pada Table 6.

Tabel 6: Rekap Nilai dan Ketuntasan Belajar Siswa

\begin{tabular}{llc}
\hline No & Aspek & Skor Hasil \\
\hline 1. & Nilai Tertinggi & 93,25 \\
2. & Nilai Terendah & 44 \\
3. & Rerata kelas & 81,06 \\
4. & Tuntas belajar (nilai > 75) & 14 siswa $(87,5 \%)$ \\
5. & Tidak Tuntas Belajar (nilai < 75) & 2 siswa $(12,5 \%)$ \\
\hline 6. & Rerata Ketuntasan 87,5\% \\
\hline
\end{tabular}

Sumber: data primer, 2015

Dari Tabel 6 di atas dapat diketahui bahwa jumlah siswa yang mencapai nilai ketuntasan mencapai 14 siswa $(87,5 \%)$, dan hanya 2 siswa yang tidak tuntas $(12,5 \%)$. Hal Ini menunjukkan bahwa proses pembelajaran pada siklus II mengalami kenaikan, sehingga target perbaikan yang ingin dicapai yaitu $80 \%$, sudah tercapai pada siklus II ini.

Proses pembelajaran mengalami peningkatan yang dapat dilihat dari indikator-indikatornya, yaitu: (1) 
kemampuan siswa untuk menentukan empat kata kunci dengan bantuan gambar yang diproyeksikan mencapai skor $86,5 \%$, dan (2) kemampuan siswa mengembangkan kata kunci menjadi bait puisi telah mencapai skor 89,06\%. Hal ini dikarenakan: (1) latihan tebak gambar yang membuat siswa lebih mudah dan percaya diri dalam menuliskan ide sesuai dengan gambar yang diproyeksikan, (2) bantuan kosa kata yang berhubungan dengan gambar yang diproyeksikan membantu siswa menentukan diksi dan mengembangkan kata kunci menjadi bait puisi, (3) panduan struktur kalimat lengkap dan tak lengkap, memudahkan siswa mengembangkan kata kunci menjadi bait puisi dengan bentuk visual yang lebih rapi.

\section{PEMBAHASAN}

Dari hasil penelitian terdapat perbedaan antara proses pembelajaran menggunakan metode ceramah/ekspositori pada tahap pra siklus dengan menggunakan media gambar yang diproyeksikan pada siklus I dan II. Deskripsi data hasil penelitian secara keseluruhan dapat dilihat pada tabel berikut.

Berdasarkan Tabel 7 di atas diperoleh data bahwa semua aspek dalam penelitian, baik hasil belajar

Tabel 7: Perbandingan Hasil Penelitian Melalui Metode Ceramah dan Gambar yang diproyeksikan

\begin{tabular}{|c|c|c|c|c|}
\hline \multirow[t]{2}{*}{ No } & \multirow[t]{2}{*}{ Aspek } & \multirow{2}{*}{$\begin{array}{l}\text { Metode } \\
\text { Ceramah/ } \\
\text { Eksposiori } \\
\text { (Pra Siklus) }\end{array}$} & \multicolumn{2}{|c|}{$\begin{array}{c}\text { Media Gambar yang } \\
\text { diproyeksikan }\end{array}$} \\
\hline & & & Siklus I & Siklus II \\
\hline 1 & Nilai Tertinggi & 77,50 & 90 & 93,25 \\
\hline 2 & Nilai Terendah & 38,75 & 40 & 44 \\
\hline 3 & Rerata Hasil Belaja & 68,50 & 74,87 & 81,06 \\
\hline 4 & $\begin{array}{l}\text { Ketuntasan belajar } \\
\text { (nilai>75) }\end{array}$ & $\begin{array}{l}4 \text { siswa } \\
(25 \%)\end{array}$ & $\begin{array}{l}8 \text { siswa } \\
(50 \%)\end{array}$ & $\begin{array}{l}14 \text { siswa } \\
(87,5 \%)\end{array}$ \\
\hline 5 & $\begin{array}{l}\text { Ketidaktuntasan } \\
\text { Belajar (nilai< }<5 \% \text { ) }\end{array}$ & $\begin{array}{l}12 \text { siswa } \\
(75 \%)\end{array}$ & $\begin{array}{l}8 \text { siswa } \\
(50 \%)\end{array}$ & $\begin{array}{l}2 \text { siswa } \\
(12,5 \%)\end{array}$ \\
\hline 6 & $\begin{array}{l}\text { Rerata kelas } \\
\text { Ketuntasan Siswa }\end{array}$ & $25 \%$ & $50 \%$ & $87,5 \%$ \\
\hline
\end{tabular}

Sumber: data primer, 2015

maupun ketuntasan siswa, menunjukkan bahwa proses pembelajaran menggunakan media gambar yang diproyeksikan hasilnya lebih tinggi daripada menggunakan metode ceramah/ekspositori. Perbandingan rerata hasil belajar dapat dilihat pada histogram berikut:

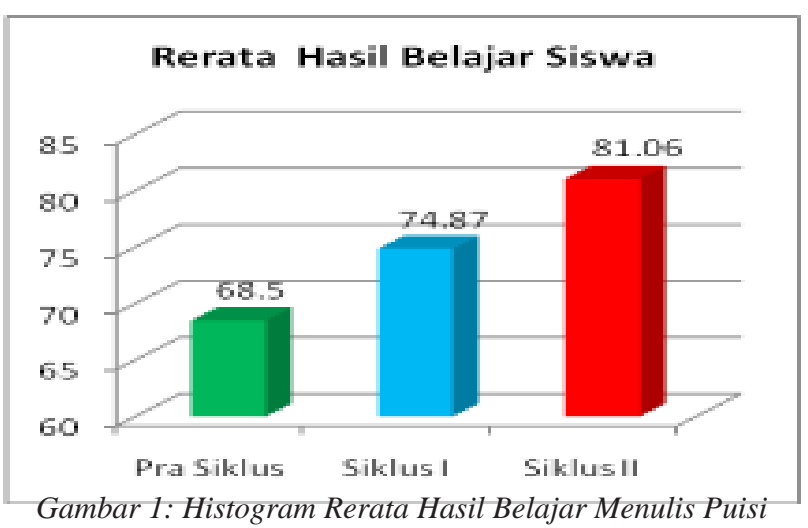

Berdasarkan histogram di atas, kemampuan siswa dalam menulis puisi menggunakan media gambar yang diproyeksikan mengalami peningkatan dibandingkan dengan metode ceramah/ekpositori. Hal tersebut dapat dilihat dari rerata hasil belajar menggunakan metode ceramah/ekspositori pada tahap pra siklus yang mencapai rerata 68,50. Kemudian setelah menggunakan media gambar yang diproyeksikan meningkat menjadi 74,87 pada siklus I, dan 81,06 pada siklus II. Meningkatnya hasil belajar siswa tersebut tidak lepas dari meningkatnya kualitas pembelajaran selama menggunakan media gambar yang diproyeksikan. Sedangkan dilihat dari rerata nilai hasil menulis puisi di atas, maka ketuntasan belajar siswa juga mengalami kenaikan yang memuaskan. Perbandingan ketuntasan belajar siswa menggunakan metode ceramah/ekspositori dan media gambar yang diproyeksikan dapat dilihat pada gambar 2 berikut ini.

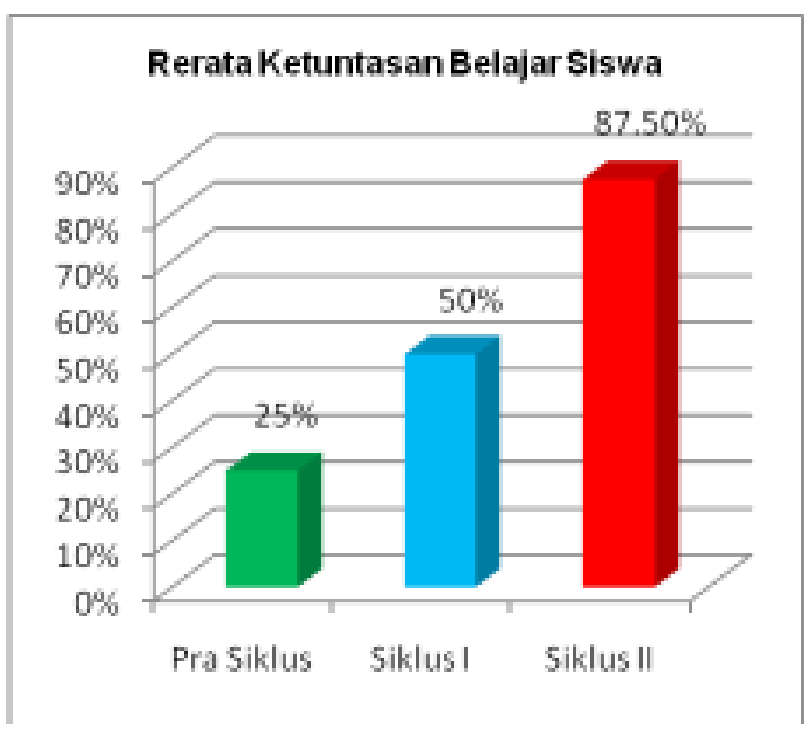

Gambar 2: Histogram Rerata Ketuntasan Belajar Siswa 
Berdasarkan histogram ketuntasan belajar dapat dilihat perbandingan tingkat ketuntasan belajar siswa menggunakan metode ceramah/ekspositori pada tahap pra siklus dengan media gambar yang diproyeksikan pada tahap siklus I dan II. Ketuntasan belajar siswa pada pra siklus atau proses pembelajaran menggunakan metode ceramah/ ekspositori baru mencapai 4 siswa atau (25\%). Kemudian, setelah menggunakan media gambar yang diproyeksikan mengalami kenaikan menjad 8 siswa (50\%) pada siklus I atau mengalami kenaikan sebanyak 25\%. Sedangkan pada siklus II naik dari 8 siswa (50\%) menjadi 14 Siswa atau (87,5\%) atau mengalami kenaikan $37,5 \%$. Jadi pembelajaran menulis puisi menggunakan media gambar yang diproyeksikan dikatakan berhasil karena bisa menaikkan kompetensi siswa dan jumlah ketuntasan belajar siswa.

Perbedaan hasil penelitian yang dilakukan oleh Maryanto (2013) dan Hidayati (2015) menggunakan media gambar mati dengan penelitian ini yang menggunakan media gambar yang diproyeksikan dapat dilihat pada histogram berikut ini.

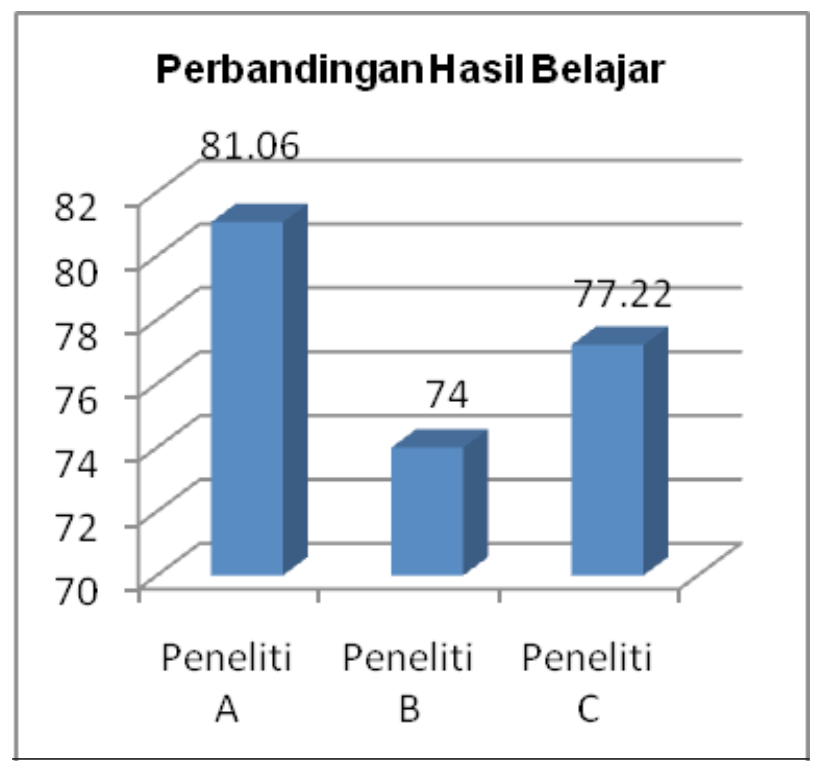

Gambar 3: Perbandingan Hasil Penelitian Pada Aspek Hasil Belajar

Keterangan:

Peneliti A: Isyani (2016), media gambar yang diproyeksikan Peneliti B : Maryanto (2013), media gambar

Peneliti C : Hidayati (2015), media gambar
Berdasarkan histogram di atas dapat dilihat perbandingan hasil belajar siswa dari ketiga peneliti. Rerata hasil belajar dari peneliti A mencapai 81,06, sementara peneliti B mencapai rerata 74 dan peneliti C mencapai 77,22. Rerata hasi belajar yang tertinggi dicapai oleh peneliti $A$ yang menggunakan media gambar yang diproyeksikan, yaitu mencapai rerata kelas 81.06, kemudian peneliti $C$ mencapai 77,22 dan peneliti B mencapai 74. Media yang digunakan oleh peneliti B dan C adalah media gambar. Hasil belajar siswa akan menentukan ketuntasan belajar siswa, karena yang mencapai nilai KKM yang sudah ditentukan akan mencapai ketuntasan belajar, sedang yang belum mencapai nilai KKM berarti belum mencapai ketuntasan belajar. Rerata ketuntasan belajar siswa dari ketiga penelitian tersebut dapat dilihat pada histogram berikut:

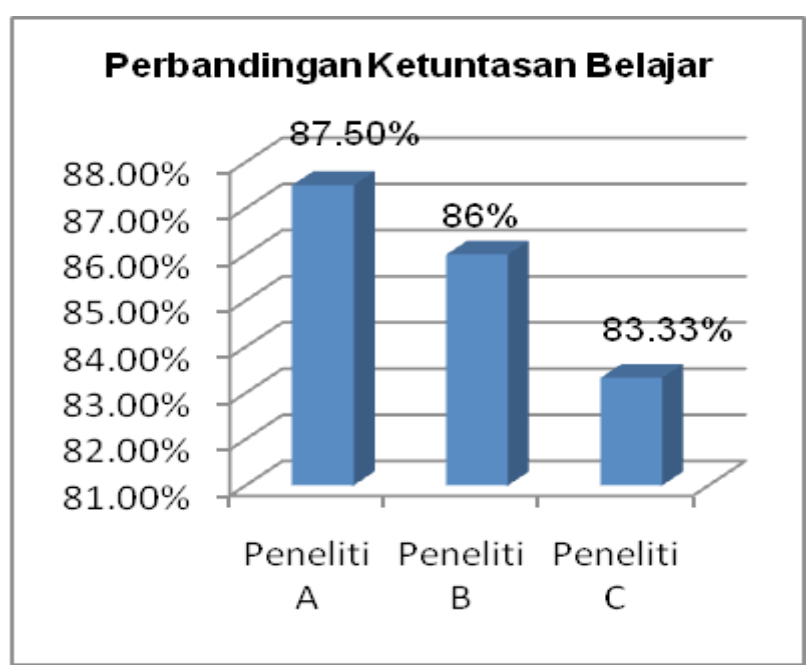

Gambar 4: Histogram Perbandingan Hasil Penelitian Pada Aspek Ketuntasan Belajar

Keterangan :

Peneliti A: Isyani (2016), media gambar yang diproyeksikan Peneliti B : Maryanto (2013), media gambar Peneliti C : Hidayati (2015), media gambar

Berdasarkan histogram perbandingan ketuntasan belajar siswa di atas dapat dilihat hasil dari ketiga peneliti. Peneliti A mencapai ketuntasan $87,50 \%$, peneliti B mencapai 86\% dan peneliti C mencapai 83,33\%. Dari capaian ketuntasan belajar yang dicapai oleh ketiga peneliti tersebut menunjukkan bahwa proses pembelajaran menulis puisi menggunakan media gambar dapat meningkatkan kompetensi siswa, 
sehingga target penelitian yang hendak dicapai oleh masing-masing peneliti bisa tercapai. Dengan demikian, dapat disimpulkan bahwa media gambar, baik gambar mati maupun gambar yang diproyeksikan, sangat efektif dalam meningkatkan hasil belajar dan ketuntasan belajar siswa. Hal itu disebabkan karena, media gambar dinilai sangat efektif menarik perhatian siswa dan mengkonkretkan konsep yang abstrak, sehingga memudahkan siswa dalam menerima materi pelajaran.

Penggunaan media gambar dan media gambar yang diproyeksikan pada ketiga penelitian ini mempunyai beberapa kelebihan dan kekurangan. Kelebihan dari media gambar antara lain: (1) dapat menarik perhatian siswa, (2) guru bisa dengan mudah menyediakan bermacam-macam gambar yang bervariatif, (3) gambar bisa digunakan berulang-ulang termasuk pada mata pelajaran yang lain. Namun demikian, ada beberapa kelemahan media gambar yaitu bahwa gambar tidak bisa bergerak dan tidak bisa mewakili sifat-sifat benda nyata, sehingga media ini kurang maksimal dalam menggali imajinasi dan pengetahuan awal siswa dalam menulis puisi.

Media gambar yang diproyeksikan mempunyai kelebihan antara lain, bisa menarik perhatian siswa karena secara otomatis semua perhatian siswa tertuju pada tayangan gambar yang diproyeksikan. Selain itu, media gambar yang diproyeksikan juga bisa dibuat semenarik mungkin dengan menambah effect suara dan animasi lainnya, sehingga menghasilkan tampilan gambar yang menarik dan memudahkan siswa dalam berimajinasi untuk menulis puisi yang menarik. Akan tetapi media gambar yang diproyeksikan ini juga mempunyai kelemahan, antara lain, yaitu; (a) guru dituntut mempunyai kemampuan khusus dalam membuat bahan belajar menggunakan media Microsoft office powerpoint, (b) memerlukan persiapan yang agak lama dalam membuat bahan belajar sebelum bisa digunakan dalam proses pembelajaran, (c) membutuhkan alat bantu lainnya yang berupa proyektor LCD. Akan tetapi beberapa kelebihan dan kekurangan pada kedua media tersebut bisa diatasi dengan saling melengkapi untuk menciptakan proses pembelajaran yang sesuai sehingga ketuntasan belajar yang diharapkan guru bisa tercapai.
Kesimpulan yang dapat diambil dari ketiga penelitian tersebut adalah bahwa proses pembelajaran dengan memanfaatkan media akan memudahkan siswa untuk mengguasai materi pelajaran, sehingga hasil belajar dan ketuntasan belajar siswa meningkat. Hasil belajar siswa pada penelitian menggunakan media gambar yang diproyeksikan mencapai skor rerata lebih tinggi daripada menggunakan media gambar, dikarenakan melaui media gambar yang diproyeksikan ditampilkan gambar dengan tampilan warna yang cerah serta tambahan animasi gerak yang sesuai benda aslinya. Hal yang demikian ini lebih memotivasi dan membantu imajinasi siswa dalam menulis puisi.

Ada sedikit perbedaan pada penelitian yang dilakukan oleh peneliti $A$, yaitu pada bagian temuan penelitian, sementara pada peneliti $B$ dan $C$ tidak mencantumkan temuan penelitian. Temuan penting dalam penelitian yang dilakukan oleh pneliti $A$, adalah bahwa dalam pembelajaran menulis puisi bagi siswa SD kelas III dengan media gambar yang diproyeksikan diperlukan empat kegiatan belajar utama, yaitu: (1) pemberian teori tentang puisi dan cara membuatnya, (2) siswa menuliskan ide puisi dengan bantuan gambar yang diproyeksikan, (3) siswa mencari empat kata kunci, dan (4) mengembangkan kata kunci menjadi bait puisi. Selain itu, berdasarkan hasil refleksi pada siklus I, perlu diberi kegiatan tambahan yang bersifat opsi, untuk mendukung kegiatan utama di atas, yaitu: (1) latihan menebak gambar pada kegiatan utama kedua. Hal ini dimaksudkan agar siswa terlatih untuk berpikir cepat dalam melihat suatu gambar, (2) disusun daftar kosa kata yang berkaitan dengan suatu gambar. Kegiatan ini sebaiknya dilakukan bersama-sama antara siswa dan guru sebelum siswa memilih kata kunci untuk puisinya, dan (3) perlu diberikan pedoman dan contoh struktur kalimat lengkap dan tidak lengkap. Dalam puisi, suatu baris dari bait tidak harus merupakan kalimat lengkap. Hal ini dilakukan pada kegiatan utama yang terakhir.

Peningkatan hasil belajar menulis puisi dengan bantuan gambar yang diproyeksikan ini sesuai dengan teori-teori belajar, salah satunya adalah teori media pembelajaran. Menurut Weidenmann dalam 
buku Perencanaan Pembelajaran, melihat sebuah foto atau gambar lebih tinggi maknanya daripada membaca atau mendengar. Melalui membaca yang dapat diingat hanya $10 \%$, dari mendengar yang diingat $20 \%$, dan dari melihat yang diingat $30 \%$. Foto/ gambar yang didesain secara baik dapat memberikan pemahaman yang lebih baik (Majid, 2012:178). Hasil penelitian ini selaras dengan teori tersebut di atas.

Dalam penelitian ini, media gambar yang diproyeksikan dapat digunakan untuk membantu siswa kelas III Sekolah Dasar Banyuripan, Kecamatan Kasihan, Bantul, Yogyakarta untuk memiliki kemampuan menulis puisi. Sebanyak 14 siswa atau $87,5 \%$ mampu mencapai nilai KKM sebesar 75, dari target keberhasilan sebanyak 80\%. Dengan demikian, pembelajaran menggunakan gambar yang diproyeksikan dikatakan berhasil meningkatkan kompetensi siswa.

\section{SIMPULAN DAN SARAN \\ Simpulan}

Simpulan yang dapat dihasilkan dari penelitian ini adalah proses pembelajaran menulis puisi menggunakan media gambar yang diproyeksikan dapat meningkatkan kualitas pembelajaran, keterampilan, dan hasil belajar menulis puisi Bahasa Indonesia pada siswa kelas III SD Banyuripan. Dibandingkan dengan media gambar mati, media gambar yang diproyeksikan lebih berhasil meningkatkan kompetensi siswa.

Temuan dalam penelitian ini adalah bahwa pembelajaran menulis puisi dengan media gambar yang diproyeksikan berhasil meningkatkan kualitas proses pembelajaran dan hasil belajar siswa dengan menggunakan 3 aktivitas pendukung, yaitu (1) latihan menebak gambar, (2) tambahan daftar kosa kata yang sesuai dengan gambar, dan (3) penjelasan pedoman struktur kalimat lengkap dan tak lengkap.

\section{Saran}

Berdasarkan hasil penelitian, pembahasan dan temuan penelitian, berikut ini beberapa saran yang dapat diajukan kepada guru SD untuk: (1) melaksanakan proses pembelajaran menggunakan media yang sesuai sebagai salah satu alternatif model pembelajaran yang menarik, karena dapat meningkatkan minat dan aktivitas siswa, sehingga meningkatkan hasil belajar dan ketuntasan belajar siswa; (2) meningkatkan kemampuan menggunakan alat peraga yang sesuai materi termasuk alat peraga multimedia berbasis komputer. Dalam hal ini, peran dan kepiawaian guru sangat dibutuhkan dalam merancang pembelajaran dengan menggunakan media yang menarik dan sesuai dengan materi pelajaran; (3) memanfaatkan media gambar yang diproyeksikan, untuk meningkatkan keterampilan menulis puisi dan hasil belajar siswa.

Saran kepada pemerintah untuk menciptakan proses pembelajaran yang kreatif dan inovatif, dengan menyediakan sarana dan prasarana yang mendukung disamping pelatihan tentang pengembangan media pembelajaran yang kreatif dan inovatif.

Saran kepada peneliti lainnya untuk mengembangkan model penelitian lebih lanjut yang dapat meningkatkan keterampilan dan hasil belajar menulis puisi Bahasa Indonesia disamping melakukan penelitian ulang dengan subyek yang berbeda, baik sekolah maupun kelas yang berbeda, dan mengembangkan media gambar yang diproyeksikan dalam bentuk Microsoft Office Powerpoint yang lebih bervariasi dan menarik.

\section{PUSTAKA ACUAN}

Aminuddin. 2010. Pengantar Apresiasi Karya Sastra. Bandung: Sinar Baru.2010.

Arsyad, Azhar. 2015, Media Pembelajaran. Jakarta: Rajawali Pers.

Arikunto, Suharsini dkk. 2010. Penelitian Tindakan Kelas. Jakarta: Bumi Aksara.

Hidayati, Rina Ayu Sih. 2015. Peningkatan Keterampilan Menulis Puisi Menggunakan Media Gambar pada Siswa Kelas III SDN Wonosari IV Kabupaten Gunung Kidul. Laporan Penelitian. FIP UNY.

Majid, Abdul.2012. Perencanaan Pembelajaran; Mengembangkan Standar Kompetensi Guru. Bandung: PT Remaja Rosdakarya Offset. 
Maryanto, Joni. 2013. Peningkatan Keterampilan Menulis Puisi melalui Model Picture and Picture dengan Media Gambar Pada Siswa Kelas V SDN Gunungpati 01. Laporan Penelitian FIP UNS.

Pradopo, Rachmat Djoko. 2014. Pengkajian Puisi. Yogyakarta: Gadjah Mada University Press.

Sanjaya, Wina. 2008. Strategi Pembelajaran Berorientasi Standar Proses Pendidikan. Jakarta: Kencana Predana Group. Sardjiyo,dkk, 2014. Pedidikan IPS di SD. Jakarta: Universitas Terbuka.

Sayuti, Suminto A. 2008. Berkenalan dengan Puisi. Yogyakarta: Gama Media.

Suryaman, Maman. 2005. Unsur Bentuk dan Makna Puisi. Yogyakarta: FB UNY.

Tarigan, Henry Guntur. 2008. Membaca Sebagai Suatu Keterampilan Berbahasa. Bandung: Angkasa.

Trianto, 2009.Mendesain Model Pembelajaran Inovatif-Progresif.Jakarta: Kencana Pernada Media Group.

Wachid B. S, Abdul, 2009, Analisis Struktural Semiotik, Yogyakarta: AK Group.

Waluyo, Herman J. 2005. Teori dan Apresiasi Puisi. Jakarta: Gramedia Pustaka Umum.

Wardhani, IGAK.dkk. 2008. Penelitian Tindakan Kelas. Jakarta: Universitas Terbuka.

Warsita, Bambang. 2008. Teknologi Pembelajaran Landasan dan Aplikasinya. Jakarta: Rineka Cipta.

Wiyatmi. 2006. Pengantar Kajian Sastra. Yogyakarta: Pustaka.

\section{UCAPAN TERIMA KASIH}

Ucapan terima kasih saya kepada Bapak Dr. Purwanto, M.Pd, atas masukan dan koreksinya terhadap konsep artikel ini sehingga pada akhirnya dapat diterbitkan. 